\title{
Redistribution of transport of hazardous materials and external safety risks: the case of rail transport in The Netherlands
}

\author{
A. V. van der Vlies \\ Department of Spatial Planning, Radboud University Nijmegen, \\ The Netherlands
}

\begin{abstract}
Since the late 1990s the debate in The Netherlands on the transport of hazardous materials by rail has intensified. The reason for this debate is the fact that most of the Dutch railway nodes are located in city centres. Risk is described by a formula in which the probability of an accident is multiplied by its effect. Although the probability might not be large, the effects of an accident can be. This article describes the effects of a new dedicated freight railroad on the risks on the adjacent area of an existing railroad. The assumption is that risks are redistributed. However this does still not match the policy goals set by the Dutch government. This argument will be built upon available transport flow figures, documents on risk standards and a reflection on the earlier mentioned formula. Keywords: redistribution of risks, rail transport of hazardous materials, external safety policy.
\end{abstract}

\section{Introduction}

After a couple of disasters and near misses in The Netherlands, the Dutch government has chosen to focus more on the enforcement of external safety policy. In this paper external safety is defined as the amount of safety due to the production, transport and/ or use of hazardous materials [1]. External safety policy aims to lower risks for civilians to be killed due to accidents with hazardous materials and to prevent economical loss due to the large number of casualties and the destruction of parts of the built up area. This paper focuses on the implications of Dutch external safety policy on rail transport for urban areas in general and on the so called Brabant Railroad and Betuwe Railroad in 
particular (see Figure 1). At the moment there is a lot of concern regarding external risks in The Netherlands [2]. Structural measures are therefore needed to prevent problems between external safety policy and urban development [3].

For the transport of hazardous materials by rail the problems concerning risks are mainly concentrated in the adjacent area of the Brabant Railroad. In 2007 a new railroad will be taken into operation. The Betuwe Railroad is designed to be a high quality and high speed freight rail connection between Germany and the Rotterdam harbor area. The railroad is not designed for the transport of people.

It is assumed that when this railroad is taken into operation, risks in the Brabant Railroad area are reduced to acceptable levels. One could say that this is a structural measure which will also result in an urban development potential for the cities along the Brabant Railroad. The Association of Netherlands Municipalities, for this matter, expects ' $a$ lot' of the Betuwe Railroad, especially for the communities in the adjacent area of the Brabant Railroad (VNG, p. 14 $[4])$.

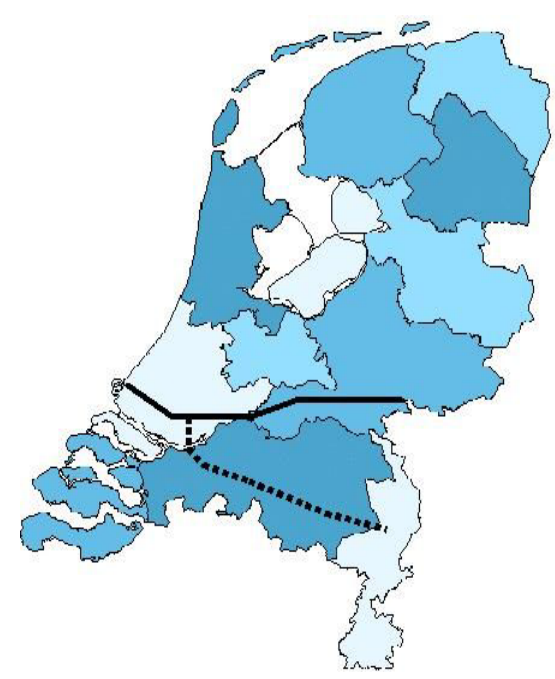

Figure 1: The Netherlands and a schematic representation of the Betuwe Railroad (black line) and the Brabant Railroad (dashed line).

The aim of this paper is to investigate whether the redistribution between the both railroads will result in a lowering of risks on the Brabant Railroad to an acceptable level and whether this is a structural measure to solve problems concerning external risks in the adjacent area of the Brabant Railroad. First, attention is paid to risks and external safety policy in The Netherlands and the Brabant Railroad in particular. Next, the effects of the new Betuwe Railroad on the transport of hazardous materials on the old Brabant Railroad will be given. This is followed by an outline on what this means for the calculated risks in the Brabant Railroad area. Finally, the paper ends with a conclusion and a discussion. 


\section{External Safety and risk at the Brabant Railroad}

As Rosmuller points out there are several definitions of risk. Basically risk consists of three components, the scenario, the probability of this scenario and the consequence of the scenario [5]. Risk is described here by a formula in which the probability of an accident is multiplied by its effect. In practice, transportation risks with hazardous materials are estimated with several mathematical models. One of them is the RBMII model [6]. This standardized model is free of use and distributed by the Dutch Ministry of Transport, Public Works and Water Management. This is done to satisfy a need for a relatively simple and standardized method to calculate risks [7]. This model will also be the benchmark model for all risk analyses to be made regarding transport of hazardous materials, except for highly difficult non-standard situations [6].

The RBMII model uses much more assumptions in its calculations than just probability and effect, but it basically boils down to this standard formula. Probability for example is calculated by multiplying data on the frequency of accidents and the probability of failure of the tank filled with hazardous materials. The frequency of accidents takes into account such facts as the speed of a rail track, the amount of level crossings and the amount of track switches. The effect of a possible derailment is calculated by such variables as the amount of hazardous materials released and their effects on people ("is the substance toxic or explosive?"), the amount of people living in the adjacent area and the distance between the center of the track and the built up area.

The calculated data can be 'visualized' in two different ways. The first one is called Individual Risk (IR). This is the probability that an unprotected person dies due to an accident with hazardous materials per year on a certain spot when this person resides here a full year. The risk is visualized by dots on a map which function as spatial contours (see Figure 2). The maximum allowed risk as laid down in Dutch law, is $1 * 10^{-6}$. This means that a risk which is lower than once every million years is found acceptable according to Dutch policy. The second way to describe risk is in terms of Group Risk (GR). This is the annual probability that a group of people dies due to a severe accident. This is visualized by using the so called $\mathrm{fN}$ curve, where f resembles the frequency of an accident and $\mathrm{N}$ the number of people that can die in an accident (see Figure 3).

The calculations made for the IR and the GR are based on two leading scenarios. For the IR the transport of category $\mathrm{C} 3$ materials (flammable liquids) is leading. Sometimes this is also influenced by toxic liquids or flammable gasses [8]. Because of the dominant influence of the C3 category, the $10^{-6}$ contour is never more than 30 meters from the Railroad. This results from the fact that a leaking tank in theory cannot create a puddle with a diameter of more than 30 meters. Moreover a minimum amount of more than 3000 tanks per year is needed to create a $10^{-6}$ contour outside of a railroad. For the GR the leading scenario is a BLEVE (Boiling Liquid Expanding Vapor Explosion). A BLEVE is caused when a tank filled with category A flammable gasses has an instant rupture combined with extreme heat and because of which the gas immediately 
catches fire to cause an explosion. This scenario can influence the GR value for more than $90 \%$.

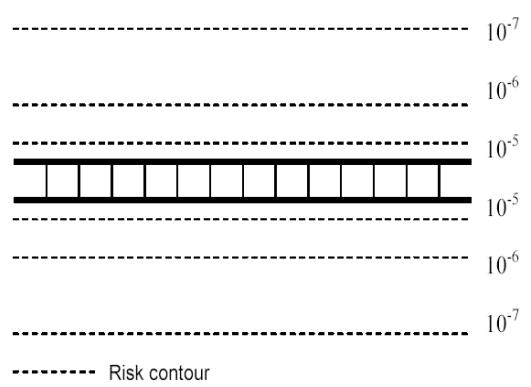

Figure 2: Schematic visualization of Individual Risk near a railroad.

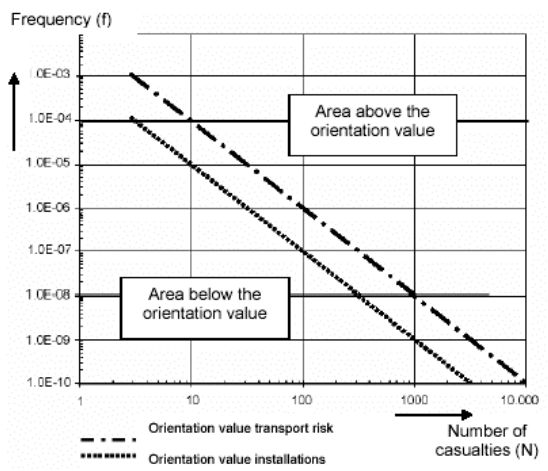

Figure 3: Schematic reproduction of Group Risk.

For the IR asserts that vulnerable objects cannot be within the $10^{-6}$ contour. When the orientation value for the GR is met, a line can be drawn in figure 3 that doesn't cross the diagonal curve representing the orientation value. The curve that is drawn is than still in the area below the orientation value. When it crosses the line and thus is drawn in the area above the orientation value, the GR is too high according to Dutch policy standards. However, the orientation value is not binding by law and acts more as a guideline for policy makers and planners to review their plans. In practice the GR orientation values are generally taken into account when deciding upon new projects with relation to urban planning [3].

Nevertheless there are a number of spots in The Netherlands where risks are 'too' high, as is shown in Figures 4 and 5. Both figures show the present situation. Figure 4 shows that within the IR $10^{-6}$ contour of the Brabant Railroad a large number of buildings are located. Figure 5 shows that there are several spots on the Brabant Railroad where the orientation value for the GR is not met, implying that the risk curve crosses the curve of the orientation value for group risk. A large number of spots with the same problem are not indicated with circles for reasons of clarity. There are forty to fifty spots where the orientation value is nearly met or violated, which means that there are forty to fifty spots where the GR is at least a factor 0.3 of the orientation value. These factors range from 0.3 to up to a factor of more than 10 times the orientation value [9].

There are six fairly large cities located adjacent to the Brabant Railroad and in all of them the quantified risk exceeds the orientation value for GR. These cities are Zwijndrecht (1), Dordrecht (2), Breda (3), Tilburg (4), Eindhoven (5) and Venlo (6). The largest city is Eindhoven with almost 210000 inhabitants and the smallest is Zwijndrecht with little over 45000 inhabitants [10]. Of these cities 
Breda and Venlo exceed the orientation value with a factor of 1 to 3. Of the other four cities Zwijndrecht, Dordrecht and Eindhoven exceed the orientation value with more than a factor 10. Apart from this they all have several buildings located within the $10^{-6}$ contours. Clearly this is due to the large amount of hazardous materials transported by rail through these cities each year.

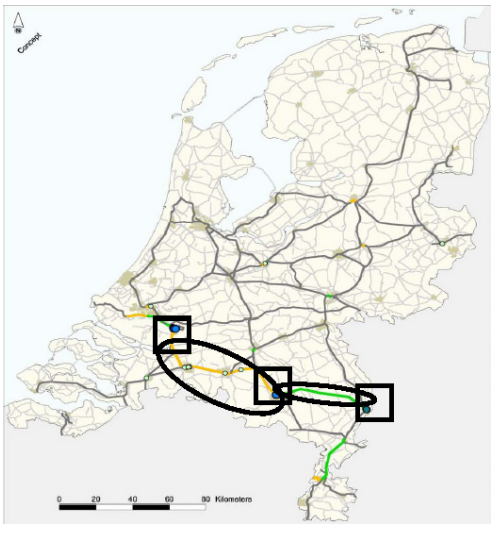

Figure 4: IR in The Netherlands: Map of The Netherlands and its freight railroad lines. The black ovals represent two parts of the Brabant Railroad where the IR $10^{-6}$ contours are located up to 20 meters from the railroad. The black squares have between 21 and 100 building located within these contours [9].

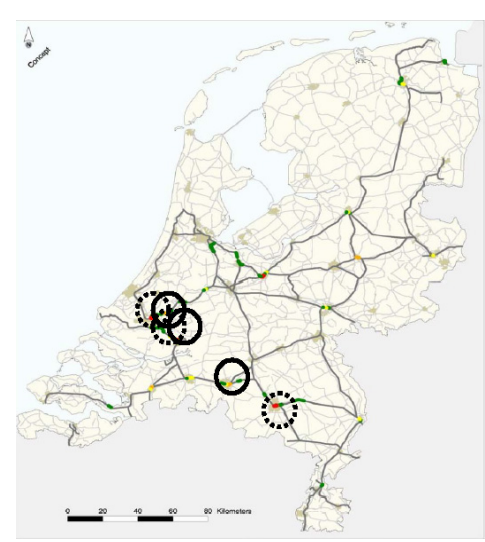

Figure 5: GR in The Netherlands: Map of The Netherlands and its freight railroad lines. The black circles represent spots which exceed the orientation value for the GR with a factor 3-10. The dashed circles exceed the GR with more than a factor 10 [9].

The general expectation is that total quantity for rail transport will grow in the future [11]. The growth numbers however are not clear with regard to various classes of hazardous materials. For category B2 a growth percentage of $-10 \%$ to $+16 \%$ is expected. However, for category A materials, from which the leading scenario is derived, a growth of $25-80 \%$ in the next 25 years is expected [12].

\section{Effects of the Betuwe Railroad on the Brabant Railroad}

In 2003 the total amount of transported hazardous materials on the Brabant Railroad was as shown in Table 1. The names of the parts of the railroad do not represent all of the cities but are deduced from official railway documents and refer to their technical name in the railroad network. The numbers (1) to (6) in the table refer to the cities as mentioned earlier in the text. 
Table 1: $\quad$ Realized transport of hazardous materials on the Brabant Railroad in 2003 in numbers of tank wagons [13].

\begin{tabular}{|l|l|l|l|l|l|l|}
\hline Name of part of the & \multicolumn{6}{|l|}{ Realized transport in 2003 per category } \\
\cline { 2 - 8 } Brabant railroad & $A$ & $B 2$ & $B 3^{*}$ & $C 3$ & $D 3$ & $D 4$ \\
\hline $\begin{array}{l}\text { (1) Kijfhoek }-(2) \\
\text { Dordrecht }\end{array}$ & 6350 & 100 & 0 & 13150 & 1800 & 1300 \\
\hline $\begin{array}{l}\text { (2) Dordrecht Lage } \\
\text { Zwaluw }\end{array}$ & 6350 & 100 & 0 & 10700 & 1800 & 950 \\
\hline $\begin{array}{l}\text { Lage Zwaluw - } \\
\text { Zevenbergsehoek - (3) }\end{array}$ & 2750 & 0 & 0 & 8200 & 1400 & 700 \\
\hline $\begin{array}{l}\text { Zevenbergsehoek } \\
\text { Breda Aansluiting }\end{array}$ & 100 & 0 & 10000 & 1800 & 950 \\
\hline $\begin{array}{l}\text { (3) Breda Aansluiting - } \\
\text { (4) Tilburg aansluiting }\end{array}$ & 4850 & 0 & 0 & 8200 & 1400 & 700 \\
\hline $\begin{array}{l}\text { (4) Tilburg aansluiting - } \\
\text { Boxtel }\end{array}$ & 4850 & 0 & 0 & 7150 & 1400 & 450 \\
\hline $\begin{array}{l}\text { Boxtel -(5) Tongelre } \\
\text { aansluiting }\end{array}$ & 4850 & $1900^{* *}$ & 0 & 8200 & 1400 & 500 \\
\hline $\begin{array}{l}\text { (5) Tongelre aansluiting- } \\
\text { (6) Venlo }\end{array}$ & 4650 & 50 & 0 & 6950 & 450 & 450 \\
\hline
\end{tabular}

*This is accounted for chloride gas which is hardly transported in The Netherlands as a whole and not foreseen to be transported on this railroad at all.

**These numbers are due to a supply route from the south which crosses the Brabant Railroad.

Table 2: $\quad$ Future transport figures on the Brabant Railroad [12].

\begin{tabular}{|c|c|c|c|c|c|c|}
\hline \multirow{2}{*}{$\begin{array}{l}\text { Name of part of the } \\
\text { Brabant railroad }\end{array}$} & \multicolumn{6}{|c|}{ Forecast for 2012 per matter category } \\
\hline & $A$ & $B 2$ & $B 3$ & C3 & D3 & D4 \\
\hline $\begin{array}{l}\text { (1) Kijfhoek - (2) } \\
\text { Dordrecht }\end{array}$ & 4500 & 100 & 0 & 3250 & 1150 & 2000 \\
\hline $\begin{array}{l}\text { (2) Dordrecht }- \text { Lage } \\
\text { Zwaluw }\end{array}$ & 4500 & 100 & 0 & 3250 & 1150 & 1000 \\
\hline $\begin{array}{l}\text { Lage Zwaluw } \\
\text { Zevenbergsehoek }\end{array}$ & - & - & - & - & - & $-*$ \\
\hline $\begin{array}{l}\text { Zevenbergsehoek - (3) } \\
\text { Breda Aansluiting }\end{array}$ & 550 & 0 & 0 & 0 & 1150 & 300 \\
\hline $\begin{array}{l}\text { (3) Breda Aansluiting - } \\
\text { (4) Tilburg aansluiting }\end{array}$ & 4400 & 0 & 0 & 0 & 1150 & 300 \\
\hline $\begin{array}{l}\text { (4) Tilburg aansluiting - } \\
\text { Boxtel }\end{array}$ & 2850 & 0 & 0 & 0 & 1150 & 300 \\
\hline $\begin{array}{l}\text { Boxtel -(5) Tongelre } \\
\text { aansluiting }\end{array}$ & 2850 & $\begin{array}{l}3650^{*} \\
*\end{array}$ & 0 & 2500 & 1150 & 300 \\
\hline $\begin{array}{l}\text { (5) Tongelre aansluiting- } \\
\text { (6) Venlo }\end{array}$ & 2300 & 0 & 0 & 0 & 0 & 0 \\
\hline
\end{tabular}

*This is accounted for chloride gas which is hardly transported in The Netherlands as a whole and not foreseen to be transported on this railroad at all.

**These numbers are due to a supply route from the south which crosses the Brabant Railroad.

When the Betuwe Railroad is taken into operation, a number of transports will be redirected from the Brabant Railroad to the Betuwe Railroad. In a 
document by rail manager Prorail, the forecast for the transport of hazardous materials by rail is given for the year 2012 and beyond. The transport flows for all categories are given as they are estimated based on current trends in transport and economy and including the Betuwe Railroad in the rail system. In the future situation the transported amount of hazardous materials on the Brabant Railroad is estimated as given in Table 2 .

\section{Effects on the calculated risk}

By comparing Tables 1 and 2, shifts in the amount of transported materials can be found. It is already pointed out that category A materials, contribute the most to the GR. Category C3 materials mainly contribute to the IR and also form the dominating category concerning the leading scenario. As is shown in table 2, the maximum amount of tank wagons is 3250 per year, which is a reduction of 9900 tank wagons. The resulting amount is little more than the 3000 tank wagons which (as noted before) is a minimum to create a IR $10^{-6}$ contour outside of the railroad. However the extra 250 tank wagons will not cause a large contour outside of the railroad [9]. Therefore there will not be any vulnerable objects within this contour and the risks will be reduced to an, in terms of Dutch policy, satisfying level.

Looking at the quantified risks for the GR and the orientation value, the category mainly influencing the GR is category A, because of the BLEVE scenario. By comparing tables 1 and 2 for this category, percentages can be calculated by dividing the estimated transport flows for the Brabant Railroad in the future situation by the transport flows of the 2003 situation. From these percentages a decline in factors can be derived. Table 3 shows the present number of category A transport, the future number of transport and the differences in percentage and factor.

Based on Table 3 it can be concluded that the group risks will lower for the total Brabant Railroad. However this does not imply that the resulting risk levels will become lower than the orientation value. The way in which risk is calculated, through multiplying the probability of an accident and the effects, implies a linear relation. This means that if the effects or the probability lowers with a certain factor, the risks will be lowered with the same factor. In this case the total quantity of transport of hazardous materials is lowered with a certain factor and therefore the probability is lowered. As seen in the right column, on all parts of the Brabant Railroad the probability is lowered with a factor between 1,1 and 1,96, except for the part from 'Zevenbergsehoek' to 'Breda aansluiting'. This is also a part of the Brabant Railroad where the population density is not that high and where consequently no problems with regards to the orientation value of the GR are expected.

As far as the other parts of the Brabant Railroad are concerned, the situations will not sufficiently improve. In Zwijndrecht and Dordrecht ('Kijfhoek Dordrecht'), Tilburg ('Tilburg - aansluiting') and Eindhoven ('Tongelre aansluiting') the GR is at least three times higher than the orientation value. Especially Zwijndrecht, Dordrecht and Eindhoven are problem areas with a GR 
of more than ten times the orientation value. Because of the linear relation this means that risks are lowered with factors between 1,1 and 1,96. To stay within the orientation value for GR, these factors should therefore be higher, up to a factor of at least ten. So, although the effects of the Betuwe Railroad are significant and the situation is improving, the future situation will not be as good as Dutch policy would prescribe it to be.

Table 3: Difference in percentages and factors of transported category A materials in the 'present' (2003) situation and in the future (2012) situation on the Brabant Railroad.

\begin{tabular}{|l|l|l|l|l|}
\hline $\begin{array}{l}\text { Name of part of the } \\
\text { Brabant railroad }\end{array}$ & $\begin{array}{l}\text { Present } \\
\text { situation }\end{array}$ & $\begin{array}{l}\text { Future } \\
\text { situation }\end{array}$ & $\begin{array}{l}\text { Difference in } \\
\text { percentage }\end{array}$ & $\begin{array}{l}\text { Difference } \\
\text { in factor }\end{array}$ \\
\hline $\begin{array}{l}\text { (1) Kijfhoek - (2) } \\
\text { Dordrecht }\end{array}$ & 6350 & 4500 & $-29 \%$ & 1,41 \\
\hline $\begin{array}{l}\text { (2) Dordrecht - Lage } \\
\text { Zwaluw }\end{array}$ & 6350 & 4500 & $-29 \%$ & 1,41 \\
\hline $\begin{array}{l}\text { Lage Zwaluw - } \\
\text { Zevenbergsehoek - }\end{array}$ & 5200 & Unclear & Unclear & Unclear \\
\hline $\begin{array}{l}\text { Zevenbergsehoek - (3) } \\
\text { Breda Aansluiting }\end{array}$ & 2750 & 550 & $-80 \%$ & 5,00 \\
\hline $\begin{array}{l}\text { (3) Breda Aansluiting - } \\
\text { (4) Tilburg aansluiting }\end{array}$ & 4850 & 4400 & $-9 \%$ & 1,10 \\
\hline $\begin{array}{l}\text { (4) Tilburg aansluiting - } \\
\text { Boxtel }\end{array}$ & 4850 & 2850 & $-41 \%$ & 1,69 \\
\hline $\begin{array}{l}\text { Boxtel -(5) Tongelre } \\
\text { aansluiting }\end{array}$ & 4850 & 2850 & $-41 \%$ & 1,69 \\
\hline $\begin{array}{l}\text { (5) Tongelre aansluiting- } \\
\text { (6) Venlo }\end{array}$ & 4650 & 2300 & $-49 \%$ & 1,96 \\
\hline
\end{tabular}

\section{Conclusion}

The aim of this paper was to investigate whether the redistribution of transport of hazardous materials between an old and a new railroad in The Netherlands will result in a lowering of risks along the old railroad, crossing several cities, up to an acceptable level. The underlying question is whether this policy strategy of building a new dedicated railroad is an attractive strategy to solve problems concerning external risks in the adjacent area of the city-crossing old railroad. In the adjacent area of the Brabant Railroad in The Netherlands there are a lot of spots where the risks exceed the goals set by Dutch government. One of the supposed solutions for less external risks at the Brabant Railroad is the new Betuwe Railroad. This dedicated freight railroad will be taken into operation in 2007 and should facilitate a large amount of the transport switching from the Brabant Railroad. As this paper points out, the transport flow of hazardous materials from the Brabant Railroad to the Betuwe Railroad is significant, but still is not enough to lower the Group Risk (GR) up to the generally accepted level or lower. For the Individual Risk (IR) asserts that the future situation shows a $10^{-6}$ contour outside of the railroad for a small part of the Brabant Railroad, but that this contour is too small to cause problems with possibly vulnerable objects. 
In The Netherlands there is no binding rule that determines that the orientation value for the GR should not be violated. Therefore it is possible to deviate from these norms when having a good motivation. This implies that new or 'extra' urban development in already densely populated city centers is still possible even when the orientation value for the GR is not met. Whether this is a smart thing to do is debatable [14]. Apart from the question if this is smart, one can also argue that this implies that either external safety is not taken seriously or that urban development ambitions will be frustrated [2]. Finally, one can also argue that lowering the transport of hazardous materials on the Brabant railroad even more, will either undermine economical growth or can cause problems elsewhere due to a shift in transport modality or due to more transport on other parts of the rail network which are possibly located in dense urban areas as well.

This article merely tends to emphasize the necessity for a new or better way of directing the transport of hazardous materials by rail. Because of the fact that in The Netherlands the Betuwe Railroad will not have a structural influence on the improvement of risks as much as pursued, consequently in the near future there will still be a lot of difficulties to combine urban development, external safety policy and transport of hazardous materials by rail. In future research done by this author, an answer will be sought on the question whether it is possible to apply other policy strategies and if so, how this should be done.

\section{References}

[1] Ministerie van VROM, 2001: 'Een wereld en een wil: werken aan duurzaamheid: Nationaal Milieubeleidsplan 4'. Den Haag.

[2] Raad voor de Verkeer en Waterstaat en de Vromraad (2003): 'Verantwoorde risico's, veilige ruimte'. Den Haag.

[3] Van der Heijden \& Van der Vlies, 2005: 'Spanning tussen stedelijke ontwikkeling en externe veiligheid: de casus Arnhem-centraal'. Tijdschrift voor Veiligheid en Veiligheidszorg. Jaargang 4, nummer 3.

[4] VNG, 2004: 'VNG-visie op Externe Veiligheid'. Vereniging Nederlandse Gemeenten, Den Haag.

[5] Rosmuller, 2001: 'Safety analysis of transport corridors'. Trail thesis series nr. S2001/6, The Netherlands Trail Research School, Delft.

[6] Ministerie van Verkeer en Waterstaat. 2006: 'Nota vervoer gevaarlijke stoffen'. Den Haag.

[7] http://www.rbmii.nl Ministerie van Verkeer en Waterstaat, 2006: 'Wat is RBMII?' Retrieved January 14, 2006 from http://www.rws.nl/rws/bwd /home/www/cgi-bin/index.cgi? site=15\&doc $=2189$.

[8] AVIV, Saxxion, 2005: Studiewijzer behorende bij module 9: QRA en transport.

[9] AVIV, Royal Haskoning, 2005: Consequentie onderzoek externe veiligheid transport gevaarlijke stoffen.

[10] http://www.nl.wikipedia.org

- Breda. (2006, February 14). Wikipedia, de vrije encyclopedie. Retrieved on 10:30, February 14, 2006 from http://nl.wikipedia.org/w/index.php? 
title $=$ Breda\&oldid $=3146244$.

- Dordrecht. (2005, September 12). Wikipedia, de vrije encyclopedie. Retrieved on 10:01, February 14, 2006 from http://nl.wikipedia.org/w/ index.php?title=Dordrecht\&oldid $=2004215$.

- Eindhoven. (2006, February 12). Wikipedia, de vrije encyclopedie. Retrieved on 10:06, February 14, 2006 from http://nl.wikipedia.org/w/ index.php?title=Eindhoven\&oldid=3139835.

- Tilburg. (2006, February 6). Wikipedia, de vrije encyclopedie. Retrieved on 10:12, February 14, 2006 from http://nl.wikipedia.org/w/ index.php?title=Tilburg\&oldid $=3077054$.

- Venlo. (2006, February 7). Wikipedia, de vrije encyclopedie. Retrieved on 10:26, February 14, 2006 from http://nl.wikipedia.org/w/index.php? title $=$ Venlo\&oldid $=3090600$.

- Zwijndrecht. (2005, December 31). Wikipedia, de vrije encyclopedie. Retrieved on 10:21, February 14, 2006 from http://nl.wikipedia.org/w/ index.php?title=Zwijndrecht\&oldid $=2740141$.

[11] Railcargo, 2005: Spoor in cijfers 2005.

[12] Prorail, 2003: 'Prognose van het vervoer van gevaarlijke stoffen per spoor: een beleidsvrije marktprognose'.

[13] Prorail, 2005: 'Spoortransport gevaarlijke stoffen 2003'.

[14] Ale, 2005: Wat legaal is, is niet altijd slim. Externe Veiligheid, jrg. 2, nr. 1 , pp. 30-31. 